\title{
Death review caused by Covid 19 in Bangladesh
}

Rajat Sanker Roy Biswas ${ }^{1}$, Jishu Deb Nath ${ }^{2}$, Fatema Emrose Nisha ${ }^{3}$

\section{List of Authors:}

1. Rajat Sanker Roy Biswas

Associate Professor

Department of Medicine

Agrabad, Chittagong

CMOSHMC

rajatbiswas76@yahoo.com

8801819808433

\section{Corresponding author}

2. Jishu Deb Nath

Associate Professor

Department of Medicine

\section{CMOSHMC}

Agrabad, Chittagong

jishudebnath2007@gmail.com

3. Fatema Emrose Nisha

Medical Officer

CMOSHMC, Agrabad

Chittagong, Bangladesh

fatemaemrosenisha11@gmail.com

Key wards: Covid 19, Co-morbidities, Outcome,

Word count: 2017

\section{Number of tables: 5}

\section{Financial support: $\mathrm{CMOSHMC}$}

Author contribution: 1. RSRB- Concept, Design, Procedure, Manuscript writing

2. JDN- Manuscript editing and writing

3. FEN- Data collection and editing 


\section{ABSTRACT}

Introduction: COVID- 19 pandemic had taken away lots of human life prematurely worldwide and death laid its icy hands also on Bangladesh. So, objectives of this study were to explore the monthly distributions, age, sex, co-morbidities, localities and duration of hospital stay among the COVID death cases.

Methods: In this observational study six months hospital death files were collected and explored for monthly distributions, age, sex, co-morbidities, localities and hospital stay. RT-PCR positive confirmed 113 COVID deaths were enrolled and suspected COVID deaths were excluded. Ethical clearance from the hospital authority was taken before hand. Data was compiled and analyzed by SPSS- 20.

Results: There was a low frequency of death in May-2021 and October-2021(7.1\% and $2.7 \%$ respectively) but more during June -2021 to September 2021 (12.4\%, 16.8\%, $42.5 \%$ and $18.6 \%$ respectively). Female deaths were little more than male deaths(53.1\% vs $46.9 \%)$. Age more than 51 years were the most vulnerable where $26(23 \%)$ deaths were at age group 51- 60 years, $39(34.5 \%)$ deaths were at 61-70 years and $22(19.4 \%)$ deaths were more than 71 years. Mean age of death was found 60.66 years and mean duration of hospital stay was found 9.45 days. Maximum duration of hospital stay was 45 days for one patient. Co-morbidities of death cases revealed 52(46.00\%) patients had DM and HTN both, 17(15.0\%) patients had HTN, 16(14.1\%) had DM, 3(2.6\%) had BA and COPD, 4(3.5\%) had CKD, 2(1.7\%) had cancer, $3(2.6 \%)$ had CVD, 19(16.8\%) had IHD and 16(14.1\%) patients had no comorbidities. Locality of the death cases revealed $44(38.9 \%)$ came from rural areas and $69(61.1 \%)$ came from urban areas.

Conclusion: Higher age group and multiple co-morbidities specially DM, HTN and IHD were related with COVID deaths mostly found in our study.

Key words: Age, COVID-19, Hospital stay, Locality, Sex 
medRxiv preprint doi: https://doi.org/10.1101/2022.01.23.22269626; this version posted January 25, 2022. The copyright holder for this preprint (which was not certified by peer review) is the author/funder, who has granted medRxiv a license to display the preprint in perpetuity.

It is made available under a CC-BY-ND 4.0 International license .

Introduction: It is December 2021, the two years that the human race is fighting a large pandemic since 12 December 2019 caused by Severe Acute Respiratory Syndrome Coronavirus-2 (SARS CoV 2) infection termed by World Health Organization (WHO) as Coronavirus Disease, COVID-19¹.

The WHO declared Covid-19 a global pandemic on 11March 2020. Illness ranges in severity from asymptomatic or mild to severe; a significant proportion of patients with clinically evident infection develop severe disease. Human-to-human transmission via droplets as well as through contact with fomites act as routes of the virus spread. Among the infected populations $80 \%$ are either asymptomatic or have mild disease, people have been going to their workplaces and even traveling internationally. Nevertheless, even though the virus is causing mild disease in many, the course of illness may be severe, leading to hospitalization and even death in elderly or those with comorbid conditions. $^{2}$

Guan et af published a report on 1099 patients with laboratory confirmed COVID-19 from 552 hospitals in China through January 29, 2020. The most common symptoms reported were fever (43.8\% on admission, and $88.7 \%$ during hospitalization) and cough $(67.8 \%)$, diarrhea $(3.8 \%)$ were uncommon. A severe form of the disease was reported in elderly and in patients with comorbidities. Mortality rate among diagnosed cases (case fatality rate) has a variable range; true overall mortality rate is uncertain, as the total number of cases (including undiagnosed persons with milder illness) is unknown.

In a study done in Bangladesh ${ }^{3}$ revealed regarding outcome of the COVID patients admitted, 85 (92.4\%) patients improved, 6 (6.5\%) died who were RT-PCR positive and $107(91.15 \%)$ improved, $9(7.7 \%)$ died who were probable cases. The death rate was little higher in our study then a study done before in Bangladesh which was $4.7 \% .{ }^{4}$ Age and gender ${ }^{5}$, duration of hospital stay and localities $^{6}$, comorbidities $^{7}$ play some important role in the overall outcome of the Covid 19. But there are scarcity of data among the patients who died of covid 19 in the context of Bangladesh 
Data of COVID are underway from the different parts of world but it is still scarce from Bangladesh regarding death revuew. Hence, objectives of this paper are to describe the Age, gender, comorbidites among the death cases of COVID 19 in a tertiary care COVID dedicated hospital of Bangladesh.

Methods: Present study was a retrospective observational study done during a six months study period in the year 2021. In the covid unit of the hospital all death files are kept and necessary informations were collected from those retrospectively. hospital death files were explored for monthly distributions, age, sex, co-morbidities, localities and hospital stay of the deceased patients. Only RT-PCR positive confirmed cases were included in the study and a total of 113 COVID deaths were found during the study periods. Suspected COVID deaths were excluded from the study. Ethical clearance from the hospital authority was taken before hand. After compilation data was compiled and analyzed by SPSS- 20 . 
medRxiv preprint doi: https://doi.org/10.1101/2022.01.23.22269626; this version posted January 25, 2022. The copyright holder for this preprint (which was not certified by peer review) is the author/funder, who has granted medRxiv a license to display the preprint in perpetuity.

It is made available under a CC-BY-ND 4.0 International license .

\section{Results:}

Table 1 showing there was low frequency of death in May and October $(7.1 \%$ and $2.7 \%)$ but more during June to September 2021( $12.4 \%, 16.8 \%, 42.5 \%$ and $18.6 \%)$

Table 2 showing age and gender distributions of death cases where female death was more than male death(53.1\% vs $46.9 \%)$. Age more than 51 years were the most vulnerable where $26(23 \%)$ were at age group $51-60$ years, $39(34.5 \%)$ were at $61-70$ years and 22(19.4\%) were more than 71 years.

Table 3 showing nean age was found 60.66 years and mean duration of hospital stay was found 9.45 days. Maximum duration of hospital stay was 45 days for one patient.

Table 4 showing co morbidities of death cases where 52(46.00\%) patients had DM and HTN both, 17(15.0\%) patients had HTN, 16(14.1\%) had DM, 3(2.6\%) had BA and COPD, 4(3.5\%) had CKD, 2(1.7\%) had cancer, 3(2.6\%) had CVD and 19(16.8\%) had IHD and $16(14.1 \%)$ patients had no co morbidities.

Table 5 showing locality of the death cases where 44(38.9\%) came from rural areas and $69(61.1 \%)$ came from urban areas.

Discussion: There was a low frequency of death in May-2021 and October-2021(7.1\% and $2.7 \%$ respectively) but more during June -2021 to September 2021 (12.4\%, 16.8\%, $42.5 \%$ and $18.6 \%$ respectively). Death toll was high during that time in our country and worldwide also. Second weve of Covid 19 was prevailing that time and as percentages of infection was more and frequency of death was also high.

Female deaths were little more than male deaths(53.1\% vs $46.9 \%)$. But earlier study done by Huang et $\mathrm{al}^{8}$ and Chen et $\mathrm{al}^{9}$ which show $73.0 \%$ male predominance but higher than that reported by Wang et $\mathrm{al}^{10}(54.3 \%)$. This male predominance may have happened due to increased foreign travel by males for occupational or educational purposes. But in the present study death toll of female patients were little higher than the male victims and the cause is yet to be explored.

Age more than 51 years were the most Mean age of death was found 60.66 years and mean duration of hospital stay was found 9.45 days. Our findings, matched that of 
Asia, for example, China ${ }^{11}$ (median age: 47 years; $41.9 \%$ female), India ${ }^{12}$ (mean age 40.3 years, $66.7 \%$ male) and other reports from Bangladesh ${ }^{13}(43 \%$ were in the age range of 21-40 years, female: male ratio 1:2.33). However, studies from America ${ }^{11}$ (median age, 63 years) and Europe ${ }^{12}$ (Median age, 67.5 years) showed higher age of patients but the same male preponderance.

Co-morbidities of death cases revealed 52(46.00\%) patients had DM and HTN both, 17(15.0\%) patients had HTN, 16(14.1\%) had DM, 3(2.6\%) had BA and COPD, 4(3.5\%) had CKD, 2(1.7\%) had cancer, 3(2.6\%) had CVD, 19(16.8\%) had IHD and 16(14.1\%) patients had no co-morbidities. Older adults and people of any age who have underlying medical conditions, such as hypertension and diabetes, have shown worse rognosis ${ }^{14}$. Diabetic patients have increased morbidity and mortality rates and have been linked to more hospitalization and intensive care unit (ICU) admissions ${ }^{14,15}$. People with chronic obstructive pulmonary disease (COPD) or any respiratory illnesses are also at higher risk for severe illness from COVID-19. ${ }^{16}$ Risk of contracting COVID-19 in patients with COPD is found to be fourfold higher than patients without COPD. There are significant differences between Bangladesh, China and the US in population demographics, smoking rates, and prevalence of comorbidities. ${ }^{17}$

Consistent with recent reports ${ }^{8}$, the percentage of patients with co morbid renal disease and malignancy was relatively low as also found in our study. Our findings have therefore added to the existing literature on the spectrum of co morbidities in patients with COVID-19 based on the larger sample sizes and representativeness of the whole patient population in Bangladesh.

Locality of the death cases revealed $44(38.9 \%)$ came from rural areas and $69(61.1 \%)$ came from urban areas. In one American study, in the rural counties, the mean prevalence of COVID-19 increased from 3.6 per 100000 population to 43.6 per 100000 within 3 weeks from April 3 to April 22, 2020. In the urban counties, the median prevalence of COVID-19 increased from 10.1 per 100000 population to 107.6 per 100 000 within the same period ${ }^{18}$. 
Patients with co morbidities should take all necessary precautions to avoid getting infected with SARSCoV-2, as they usually have the worst prognosis. !ere is a need for a global public health campaign to raise awareness, on reducing the burden of these co morbidity illnesses causing deaths in COVID-19-infected patients.

\section{Declarations}

Ethics approval and consent to participate- Taken

Consent for publication: Taken

Availability of data and material: Yes

Competing interests: None

Funding: None

Authors' contributions: RSRB- Concept, Design, Procedure, Manuscript writing, JDNManuscript editing and writing, FEN- Data collection and editing

Acknowledgements: CMOSHMC Authority

\section{References:}

1. Chen N, Zhou M, Dong X, Qu J, Gong F, Han Y. Epidemiological and clinical characteristics of 99 cases of 2019 novel coronavirus pneumonia in Wuhan, China: a descriptive study. Lancet . 2020 ;15;395(10223):507-513.

2. Guan W, Ni Z, Hu Y, et al. Clinical characteristics of coronavirus disease 2019 in China. N Engl J Med 2020. doi:10.1056/NEJMoa2002032

3. Biswas RS, Nath JD,Barua PK, Karim MR, Jahan S, Islam MS, et al. Clinicopathological features and outcome of COVID-19 - Early experiences from three COVID hospitals, Chittagong, Bangladesh. J Sci Soc 2021;48:15660.

4. Mohiuddin Chowdhury AT, Karim MR, Mehedi HH, Shahbaz M, Chowdhury MW, Dan G, et al. Analysis of the primary presenting symptoms and 
hematological findings of COVID-19 patients in Bangladesh. J Infect Dev Ctries 021;15:214-23

5. Biswas RSR* Nath JD, Barua PK, Uddin3 MN, Safa JFS, Karim MJ et al. Relation of Age and Sex Variations with Outcome of COVID-19 Patients : Three Months Data from A COVID Dedicated Hospital from Bangladesh. Chattagram International Medical College Journal 2021; 6(1): 8-11

6. Nath JD, Biswas RSR. Outcome of coronavirus disease 2019 in relation to duration of hospital stay and locality in a tertiary hospital of BangladeshKasr Al Ainy Medical Journal 2020:26:115-119

7. Mowla SGM, Aad KAK, Kabir A, Biswas S, Islam MR, Banik GC, et al. Clinical profile of 100 confirmed COVID-19 patients admitted in Dhaka Medical College Hospital, Dhaka, Bangladesh. J Bangl Coll Phys Surg 2020; 38:29-36.

8. Huang C, Wang Y, Li X, Ren L, Zhao J, Hu Y et al. Clinical features of patients infected with 2019 novel coronavirus in Wuhan, China. Lancet 2020;395:497506.

9. Chen N, Zhou M, Dong X, Qu J, Gong F, Han Y, et al. Epidemiological and clinical characteristics of 99 cases of 2019 novel coronavirus pneumonia in Wuhan, China: A descriptive study. Lancet 2020;395:507-13

10. Wang D, Hu B, Hu C, Zhu F, Liu X, Zhang J, et al. Clinical characteristics of 138 hospitalized patients with 2019 novel coronavirus-infected pneumonia in Wuhan, China. JAMA 2020;323:1061-9.

11. Guan WJ, Ni ZY, Hu Y, Liang WH, Ou CQ, He JX, et al. Clinical characteristics of coronavirus disease 2019 in Hina. N Engl J Med 2020;382:1708-20.

12. Gupta N, Agrawal S, Ish P, Mishra S, Gaind R, Usha G, et al. Clinical and epidemiologic profile of the initial COVID-19 patients at a tertiary care centre in India. Monaldi Arch Chest Dis 2020;90:193-6.

13. Hossain I, Khan MH, Rahman MS, Mullick AR, Aktaruzzaman MM. The epidemiological characteristics of an outbreak of 2019 novel coronavirus diseases (COVID-19) in Bangladesh: A descriptive study. JMSCR 2020;08:544-51 
14. Singh AK, Gupta R, Ghosh A, Misra A. Diabetes in COVID-19: prevalence, pathophysiology, prognosis, and practical considerations. Diabetes Metab Syndr Clin Res Rev. 2020;14(4):303

15. Hossain I, Mullick AR, Khan MH, Aktaruzzaman M, Rahman S, Tuhin SGN, et al. Impacts of Conventional Oxygen!erapy on COVID-19 Patient in Intensive Care Unit (ICU). JMedSci ClinRes. 2020;08(08):183-9.

16.Zhao Q, Meng M, Kumar R, Wu Y, Huang J, et al. !e impact of COPD and smoking history on the severity of COVID-19: a systemic review and metaanalysis. J Med Virol. 2020;10:10-12

17. Hossain I, Mullick AR, Khan MH, Halim KS, Aktaruzzaman MM, Nabi SG, Rahman S, Shahin M. Comorbidity and it's Impact on COVID-19 A $\square$ ected Patients in COVID-19 Dedicated Hospital of Bangladesh Bangladesh Med J. 2020; 49(1):19-22

18. Paul R, Arif A, Adeyemi O, Ghosh S, Han D. Progression of COVID-19 from urban to rural areas in the United States: a spatiotemporal analysis of prevalence rates. J Rural Health 2020; 30:10-14. 


\section{Tables}

Table 1: Monthly distribution of death

\begin{tabular}{|c|r|r|}
\hline Months of year 2021 & Frequency & Percent \\
\hline May & 8 & 7.1 \\
June & 14 & 12.4 \\
July & 19 & 16.8 \\
August & 48 & 42.5 \\
September & 21 & 18.6 \\
October & 3 & 2.7 \\
Total & 113 & 100.0 \\
\hline
\end{tabular}

Table 2: Relation of sex and age group of death cases

\begin{tabular}{|ll|r|r|r|}
\hline \multirow{2}{*}{ Age groups } & \multicolumn{2}{|c|}{ Sex } & \multirow{2}{*}{ Total } \\
\cline { 2 - 4 } & \multicolumn{1}{|c|}{ Female } & \multicolumn{1}{c|}{ Male } & \\
\hline \multirow{3}{*}{ Age } & $<40$ years & $10(8.8 \%)$ & $3(2.7 \%)$ & $13(11.5 \%)$ \\
Group & $41-50$ years & $8(7.1 \%)$ & $5(4.4 \%)$ & $13(11.5 \%)$ \\
& $51-60$ years & $17(15 \%)$ & $9(8 \%)$ & $26(23 \%)$ \\
& $61-70$ years & $14(12.4 \%)$ & $25(22.1 \%)$ & $39(34.5 \%)$ \\
Total & $>71$ years & $11(9.7 \%)$ & $11(9.7 \%)$ & $22(9.4 \%)$ \\
\hline
\end{tabular}


medRxiv preprint doi: https://doi.org/10.1101/2022.01.23.22269626; this version posted January 25, 2022. The copyright holder for this preprint (which was not certified by peer review) is the author/funder, who has granted medRxiv a license to display the preprint in perpetuity.

It is made available under a CC-BY-ND 4.0 International license .

Table 3: Mean age and duration of hospital status

\begin{tabular}{|l|c|c|c|c|c|}
\hline & $\mathrm{N}$ & Minimum & Maximum & Mean & $\begin{array}{c}\text { Std. } \\
\text { Deviation }\end{array}$ \\
\hline Age & 113 & 11 & 90 & 60.66 & $\begin{array}{r}14.531 \\
6.981 \\
\text { Hospital stay }\end{array}$ \\
\hline
\end{tabular}

Table 4: Co morbidities of the patients

\begin{tabular}{|l|r|r|}
\hline & Frequency & Percent \\
\hline DM+HTN & 52 & 46.00 \\
HTN & 17 & 15.0 \\
DM & 16 & 14.1 \\
BA & 3 & 2.6 \\
COPD & 3 & 2.6 \\
CKD & 4 & 3.5 \\
Cancer & 2 & 1.7 \\
CVD & 3 & 2.6 \\
IHD & 19 & 16.8 \\
No comorbidities & 16 & 14.1 \\
\hline
\end{tabular}


medRxiv preprint doi: https://doi.org/10.1101/2022.01.23.22269626; this version posted January 25, 2022. The copyright holder for this preprint (which was not certified by peer review) is the author/funder, who has granted medRxiv a license to display the preprint in perpetuity. It is made available under a CC-BY-ND 4.0 International license.

Table 5: Locality of the death cases

\begin{tabular}{|l|r|r|}
\hline & Frequency & \multicolumn{1}{|c|}{ Percent } \\
\hline Rural & 44 & 38.9 \\
Urban & 69 & 61.1 \\
Total & 113 & 100.0 \\
\hline
\end{tabular}

